\title{
Beneficial Ownership Provisions In Tax Treaties Between Developed And Developing Countries: The Canada/South Africa Example
}

Lee-Ann Steenkamp, University of the Western Cape, South Africa

\begin{abstract}
In the years since the Organisation for Economic Cooperation and Development (OECD) adopted its first draft tax treaty in 1963, the world has experienced an astonishing surge in international trade and investment. The tax treatment of these cross-border transactions is affected by double tax agreements. As tax treaty networks will likely continue to expand, concerns about tax treaty abuse might be expected to grow. The extent to which a country's tax treaty policy favours developing countries - or not - depends upon the extent to which the country is prepared to adopt provisions from the UN model tax convention as opposed to the OECD model. Developing countries, in particular, should carefully consider the design of their tax treaties so as to effectively combat tax avoidance without sacrificing foreign direct investment. To this end, the Canada/South Africa tax treaty is compared and contrasted with these two models. The concept of beneficial ownership is reviewed in this context. It is contended that a general definition in South Africa's Income Tax Act of 'beneficial ownership' would assist in the interpretation of the term for the purposes of South Africa's tax treaties. It is submitted that the scope for the source taxation of passive investment income (viz. dividends, interest and royalties) in the developing country could be magnified through treaty negotiations.
\end{abstract}

Keywords: Beneficial Ownership; Dividend; Double Tax Agreement; Interest; Organisation for Economic Cooperation and Development; Royalties; South Africa; Tax Treaty; Treaty Shopping; Withholding Tax

\section{INTRODUCTION}

$\mathrm{n}$ the years since the Organisation for Economic Cooperation and Development (OECD) adopted its first draft tax treaty in 1963, the world has experienced an astonishing surge in international trade and investment. The tax treatment of these cross-border transactions is affected by tax treaties, which now number roughly 2500 (Bakhru \& Gupta, 2012). ${ }^{1}$ It is trite that the term 'tax avoidance' refers to the use of legal methods in arranging one's tax affairs so as to pay less tax, in contrast with the term 'tax evasion' which is typified by fraud and deceit (De Koker, 2011:par19.1; Haupt, 2012:49). Abusive tax avoidance refers to artificial or contrived arrangements, with little or no actual economic impact upon the taxpayer (SARS, 2005:4).

The challenge of gauging abusive tax avoidance is even more acute in the international arena, where the tax consequences of transactions and arrangements are governed by the interaction of different domestic tax laws as well as bilateral tax treaties (Duff, 2011:483). ${ }^{2}$ The tax avoidance scheme that is employed in respect of tax treaties is often referred to as 'treaty shopping'. This term denotes the use of double taxation treaties by the residents of a non-treaty country in order to obtain treaty benefits that are not intended to be available to them (Oguttu, 2007:238).

\footnotetext{
${ }^{1}$ This number is based on the treaties which use the UN model or OECD model.

${ }^{2}$ The author further pertinently remarks that 'the contours and very existence of an international tax regime is a matter of ongoing debate'.
} 
The object of treaty shopping is to locate the source of income in the country with the lower tax rate (Reinhold, 1999:670). ${ }^{3}$

Implementing an appropriate tax policy is crucial, as the revenue that developing countries are able to raise from the income earned in their countries on cross-border trade and investment flows is often significant and critical for the development of their economy and for raising the standard of living of their impoverished residents (Brooks, 2009:2). ${ }^{4}$

\section{RESEARCH OBJECTIVE, METHOD AND SCOPE}

The objective of this paper is to compare and contrast the tax treaty policy in respect of the beneficial ownership provisions embodied in the Canada/RSA tax treaty (South Africa, 1997) with the model tax conventions developed by the OECD and the United Nations (UN). ${ }^{5}$ This exercise will assist in determining:

- $\quad$ The extent to which the treaty expands (or not) the scope for the source taxation of passive investment income; and

- $\quad$ The policy it reflects on withholding tax rates on passive income.

This paper will examine the concept of beneficial ownership as contained in double tax agreements between developed and developing countries. Accordingly, it is considered well beyond the scope of this study to also address the concepts of residence and permanent establishment.

\section{Rationale for Comparing Canada and South Africa}

It must be borne in mind that a model tax convention should embrace the twin goals of eliminating double taxation and also preventing undertaxation (McIntyre, 2005:2). ${ }^{6}$ According to Brooks (2009:2), in most tax treaties these dual objectives are achieved, in part, by effectively reducing the tax base of the source country (usually the lower-income country) and thus increasing the tax revenue of the residence country (usually the higher-income country).

Notwithstanding that there is no established convention for the designation of 'developed' and 'developing' countries or areas in the UN system, in common practice, the UN Statistics Division (2013) considers Canada a developed region. According to the same system, South Africa is classified as a developing country. Furthermore, based on criteria espoused by the World Bank (2013), Canada is categorised as a high-income country and South Africa as a middle-income country.

The OECD acknowledges that Canada has an extensive history of exchanging information for tax purposes, during which time it has established a strong framework to ensure the elements for effective availability and access to relevant information are in place (OECD, 2011:7). Moreover, Canada has one of the largest tax treaty networks among developed countries (Duff, 2010:1). As such, Canada was selected as a proxy for developed countries.

\footnotetext{
${ }^{3}$ According to the author, treaty shopping can be typified by tax-haven structures with three characteristics: (1) the owner or owners of the entity were not resident in the jurisdiction in which the company was formed, (2) the entity had few, if any, assets in the jurisdiction, and (3) the entity was subject to little or no tax in the jurisdiction.

${ }^{4}$ The author also observes that the design of the tax treaties a country enters into is indicative of the balance of interest group power in that country, the prevailing ideas, the ambitions of its politicians, the institutions of government and other variables that might influence public policy making in the country.

${ }^{5}$ Admittedly, a developing country might not have as much influence over its tax treaty design when negotiating with a developed country. Nevertheless, developing countries should be cognisant of the principles embodied in the OECD and UN treaty models, especially those contained in the UN model which favour the source country.

${ }^{6}$ The author quotes from the League of Nations report (1926) as follows on this dual goal: 'The most elementary and undisputed principles of fiscal justice, therefore, require that the experts should devise a scheme whereby all incomes would be taxed once, and once only.'
} 


\section{Comparative Analysis}

Brooks (2009) conducted an extensive research project during 2008, analysing the 53 tax treaties that Canada has entered into between 1988 and June 2008. As the Canada/RSA tax treaty was signed into force in May 1997, this treaty was automatically included in Brooks' analysis. Brooks' study is used as a basis for comparative analysis in this paper. In the period June 2008 to 31 December, 2012, Canada entered into three additional treaties with Colombia, Greece and Turkey. Accordingly, this paper has incorporated these three treaties into the research findings of Brooks' analysis. Henceforth, all references to treaties in Brooks' study will also include Colombia, Greece and Turkey.

\section{Background to the OECD and UN Models}

In 1963 the OECD Model Tax convention on Income and Capital ('OECD model') was prepared by developed countries of the world and embodies rules and proposals by capital exporting countries (Oguttu, 2007:242). As it was drafted by representatives of major western industrialised countries, lower-income, developing countries were concerned that it resulted in too large a reduction in source country tax (Brooks, 2009:2).

The developing countries responded to the success of the OECD model by developing their own model convention under the auspices of the UN in 1980. According to Oguttu (2007:242), this model has been drafted between developed and developing countries and attempts to reflect the interests of developing countries. Although it is based upon the OECD model, the UN Model Double Taxation Convention between Developed and Developing Countries ('UN model') retains much greater source country taxation.

The third prominent tax treaty model is the United States model which is followed by most treaties that the United States has signed with other countries, including South Africa (Oguttu, 2007:242). As the Canada/RSA tax treaty will be examined, the United States model is not considered relevant for the purposes of this comparative analysis.

The acceptance of the OECD model over other available standards, like the UN model for example, could possibly be explained by the fact that the OECD model is sponsored by the most developed countries of the world that are, not coincidentally, also the major capital exporting countries.

Although OECD-type tax treaties are often fraught with tax avoidance pitfalls and the potential loss of tax revenue, developing countries have some powerful incentives to enter into these with developed countries. One incentive induces developing countries to follow the OECD model for fear of driving foreign direct investment away to competing jurisdictions (if all other conditions are equal) (Baistrocchi, 2008:383). Another incentive is that the OECD-based tax treaty network conceivably produces network externalities for its members that are unavailable to non-members (Baistrocchi, 2008:383). ${ }^{7}$

Notwithstanding that the OECD model was 'extremely effective' in eliminating most of the common types of double taxation, it does not appear very effective in eliminating international tax avoidance and evasion (McIntyre, 2005:5). A more recent response by the OECD to this global phenomenon of tax arbitrage was the creation by the Committee on Fiscal Affairs of the new Treaty Relief and Compliance Enhancement (TRACE) Group in January 2010 (OECD, 2013). ${ }^{8}$

While this paper will compare the Canada/RSA tax treaty to the two model tax conventions widely in use in global tax economies; i.e., the OECD and UN models, mention should be made of another influential group of

\footnotetext{
${ }^{7}$ The author explains that these networking externalities include the minimisation of communication and enforcement costs, the provision of a number of procedures for minimising international double taxation and a credible commitment to predictability and legal stability.

${ }^{8}$ The objectives of TRACE are two-fold: (a) to develop treaty relief systems that are as efficient as possible, in order to minimise administrative costs and allocate the costs to the appropriate parties; and (b) to identify solutions that enhance countries' abilities to ensure proper compliance with tax obligations, from the perspective of both source and residence countries.
} 
countries; namely, the G20. ${ }^{9}$ The emergence of the G20 as an economic policy leader does not alter the marketleader status of the OECD in developing tax standards and guidelines (Christians, 2010:20). It could, however, provide an opportunity to syndicate OECD policy positions under the new, more inclusive and representative label of G20-endorsed 'internationally agreed tax standards' (Christians, 2010:20).

One interpretive approach to challenge tax abuse involves the concept of 'beneficial ownership' which is addressed in the next paragraph.

\section{BENEFICIAL OWNERSHIP}

\section{Introduction}

Beneficial ownership might be regarded as one of the most important concepts used in tax treaties. In general terms, it limits the benefit of treaty-reduced withholding taxes on dividends, interest and royalties to recipients who are beneficial owners of such income (Li, 2012:187).

Paragraph 10 of the OECD model commentary on Art 1 suggests the use of a 'beneficial ownership' clause as one of the anti-abuse provisions that can be used to deal with source taxation of specific types of income set out in articles 10,11 and 12 of the OECD model. The concept of 'beneficial ownership' determines the eligibility of residents of contracting states for the reduction or elimination of source country withholding taxes on interest, royalties and dividends (Duff, 2010:11). These words are generally understood to exclude intermediaries, such as nominees and agents who might be interposed between the payer and the ultimate beneficiary.

According to the OECD model commentary to Art 11 where an item of income is received by a resident of a contracting state acting in the capacity of agent or nominee it would be inconsistent with the object and purpose of the OECD model for the state of source to grant relief or exemption merely on account of the status of the immediate recipient of the income as a resident of the other contracting state (OECD, 2010:187).

Because the term has no specific meaning in the domestic tax law of most countries, the way in which domestic courts should interpret this treaty-originated concept has been the subject of much scholarly debate (see, amongst others, Avi-Yona \& HJI Panayi, 2010; Baker, 2008; Elliffe, 2009; Vogel, 1977; Van Weeghel, 1998). It is not, however, the objective of this study to contribute to that debate. Instead, the next paragraph will briefly highlight the interpretational process adopted in South Africa.

\section{Interpretation of the Term 'Beneficial Ownership' from a South African Perspective}

The interpretation of the term 'beneficial owner' continues to give rise to difficulties. The term 'beneficial ownership' has been adopted in most bilateral tax treaties, but defined in none. Neither the OECD model nor its commentary explicitly defines this term. One of the main problems is whether the term has to be construed under the domestic laws of the State applying the tax treaty or whether it has an autonomous treaty meaning (De Broe, Goyette, Martin, Rohatgi, Van Weeghel \& West, 2011:388). Its meaning is thus left to be interpreted under Art 3(2) of the OECD model.

For common law jurisdictions, such as Canada and South Africa, this approach is consistent with Article $3(2)$ of the OECD model, which stipulates that a term that is not defined in a treaty shall, unless the context otherwise requires:

have the meaning that it has at that time under the law of that State for the purposes of the taxes to which the Convention applies, any meaning under the applicable tax laws of that State prevailing over a meaning given to the term under other laws of that State.

The UN model reproduces this wording in its corresponding Art 3(2).

\footnotetext{
${ }^{9}$ The G20 is an international network of finance ministers and central bankers from eleven developed countries and eight lessdeveloped countries, as well as representatives from the European Union, the International Monetary Fund and the World Bank.
} 
The question now arises as to the relevant law of the contracting state that should be used in interpreting this term. The OECD model commentary to Art 3 provides that reference must be made to the relevant provision of the domestic law of a contracting state, whether or not a tax law (OECD, 2010:82). However, where a term is defined differently for the purposes of different laws of a contracting state, the OECD model commentary determines that the meaning given to that term for purposes of the laws imposing the taxes to which the Convention applies shall prevail over all others, including those given for the purposes of other tax laws (OECD, 2010:82).

Therefore, in South Africa, the legislation that is relevant in this regard is the Income Tax Act 58 of 1962, as amended (the Act). The concept of 'beneficial ownership' is not found in statute law for tax purposes and is unknown in South African Common law, despite some references in respect to dividends (Meyer, 2010:3). Section 64D of the Act is part of the new dividends tax provisions and defines a 'beneficial owner' as 'the person entitled to the benefit of the dividend attaching to the share.' This definition therefore only applies in the context of dividends tax. Consequently, and somewhat problematically, the Act contains no general definition of the term 'beneficial ownership' which applies to the Act as a whole.

This hurdle could potentially be surmounted by the interpretive approach embodied in the Constitution of the Republic of South Africa Act 108 of 1996 (the Constitution). In terms of section 108(2) of the Act, read with section 231 of the Constitution, when the national executive of South Africa enters into a double taxation agreement with the government of any other country, and the agreement is ratified and published in the Government Gazette, its provisions are effective as if they had been incorporated into the Act.

It is perhaps pertinent at this stage to point out that there are dissenting opinions about the status of the models (and their commentary) as international law. Du Plessis (2012:52) provides an informative synthesis of scholarly opinion on the status of tax treaties in South African law and remarks that the South African courts have not explicitly pronounced on the status of the OECD commentaries and that they seem to refer to the OECD commentaries without providing reasons for doing so.

On the premise that the models and commentaries are not international law, these will not form part of South African domestic law in terms of the Constitution (Du Plessis, 2012:44). ${ }^{10}$ However, even if such a treaty is considered as part of the Act, the lack of a definition of the term 'beneficial ownership' in the Act implies that it cannot be relied on to determine the treaty meaning of this term (Oguttu, 2007:252). This paper agrees with Oguttu's (2007:252) recommendation that a definition of 'beneficial ownership' be included in the Act to assist in the interpretation of the term for the purposes of South Africa's tax treaties.

At any rate, the withholding tax regime pertaining to interest, royalties and dividends is discussed below.

\section{Interest Income}

The OECD proposes a withholding tax on interest of 10 percent in Article 11(2). The OECD model commentary to Art 11(1) considers this a reasonable maximum, bearing in mind that the state of source is already entitled to tax profits or income produced in its territory by investments financed out of borrowed capital (OECD, 2010:207).

The UN model does not set a particular rate, but it is assumed that a higher rate might be appropriate where the treaty partner is a lower-income country (Brooks, 2009:12). Canada has negotiated withholding tax rates of 10, 12.5 or 15 percent, depending on the treaty partner. According to Brooks (2009:12), the withholding tax was set at 10 percent for all high- and middle-income countries with which Canada has negotiated treaties since 1988; for the 21 low-income countries, in twelve treaties the rate is 10 percent, in one treaty it is 12.5 percent, in seven treaties it is 15 percent, and in one treaty the rate is non-reciprocal. In the Canada/RSA treaty, the withholding tax rate in Art $11(2)$ is set at 10 percent, thereby following the proposed 10 percent of the OECD model (see Table 1).

\footnotetext{
${ }^{10}$ The author contends (at 52) that the Constitution does not oblige a court to interpret the Act in a way that is consistent with the OECD model or its commentary.
} 
Table 1: Comparison of Withholding Tax Rates for Interest Income

\begin{tabular}{|l|c|}
\hline Canada/RSA treaty & $10 \%$ \\
\hline Canada's treaties with high and middle-income countries & $10 \%$ \\
\hline Canada's treaties with low-income countries & $10 \%, 12.5 \%$ or $15 \%$ \\
\hline OECD model & $10 \%$ \\
\hline UN model & None prescribed \\
\hline
\end{tabular}

The UN model commentary notes that members from developing countries agreed to the solution of taxation by both the country of residence and the source country embodied in Art 11, paragraphs 1 and 2, of the OECD model, but found the ceiling of 10 percent of the gross amount of the interest mentioned in paragraph 2 unacceptable. Since the former Group of Experts was unable to reach a consensus on an alternative ceiling, the matter was left to bilateral negotiations.

It is argued in the UN model commentary to Art 11 that the decision not to recommend a maximum withholding rate can be justified under current treaty practice (UN, 2012:194). The withholding rates for interest adopted in developed/developing country tax treaties range more widely than those for dividends - between complete exemption and 25 percent. However, some developing countries have reduced the interest withholding rate to attract foreign investment; several of them have adopted rates at or below the OECD rate of 10 percent.

In addition to low withholding rates, exemptions from the taxation of certain types of interest income will also erode the tax revenues of source countries. Canada offers relatively few exemptions from withholding tax on interest in its tax treaties. In all but three of the treaties negotiated since 1988, an exemption for government-related interest payments is included (Brooks, 2009:12). South Africa is not one of the three countries.

Canada's treaties with high-income and middle-income countries also frequently include exemptions for pension-related entities, exemptions for credit sales of equipment and merchandise and exemptions for late payment penalties (Brooks, 2009:12). In Canada's tax treaties with low-income countries, only four include an exemption for interest income (aside from government-related interest payment) and in each case, it is for pension-related entities. This low number of exemptions might be compared to the eleven tax treaties with middle-income countries that include an exemption for some type of interest payment (other than the government-related interest payments). Per Art 11(3) of the Canada/RSA tax treaty, the treaty contains no government-related interest payment exemptions.

\section{Royalties}

The OECD model proposes a zero rate of withholding tax on royalty payments. Article 12(1) lays down the principle of exclusive taxation of royalties in the state of the beneficial owner's residence. However, the UN model deviates from this position, but does not prescribe a fixed percentage of withholding tax. According to the UN model commentary to Art 12, since the former Group of Experts reached no consensus on a particular rate for the withholding tax to be charged on royalties on a gross basis, the rate should be established through bilateral negotiations (UN, 2012:210).

The UN model Article 12(1) omits the word 'only' from the corresponding provision of the OECD model, which provides that 'royalties arising in a Contracting State and beneficially owned by a resident of the other Contracting State shall be taxable only in that other State'. Paragraph 2 of the UN model is an addition flowing logically from the premise underlying paragraph 1 , which is that royalties may be taxable in the source country as well as the residence country. The UN model commentary to Art 12 remarks that, by providing for taxing rights in respect of royalties to be shared between the state of residence and the state of source, the UN model departs from the principle of exclusive residence state's right to tax provided in the OECD model (UN, 2012:208).

The royalties articles also often contain exemptions from withholding tax. Canada frequently negotiates exemptions (or lower rates of withholding tax) for royalties related to cultural goods; for example, literary works, patents, information concerning industrial, commercial, or scientific experience and computer software. Many of these exemptions are presumably requested because Canada grants an exemption from withholding tax in its domestic tax law for these kinds of payments. 
Canada is much more likely to include exemptions from royalty withholding tax in its tax treaties when the treaty partner is a high-income country. According to Brooks (2009:13), only three tax treaties with high-income countries contain no exemptions, compared to nine treaties with middle-income countries and seventeen treaties with low-income countries. Of the seventeen treaties with low-income countries, eight include reductions from the standard withholding tax rate provided for in the treaty for some kinds of royalty payments, thereby reducing the tax revenues collected by the source country from income from these types of royalty payments.

Canada charges withholding tax on royalties in all its tax treaties. Since 1988, Canada has negotiated tax treaties with rates of 10,12.5, 15 and 20 percent rates; for all high- and middle-income countries the rate is 10 percent; for low-income countries, Canada has negotiated a rate of 10 percent in fourteen tax treaties, 12.5 percent in one tax treaty, 15 percent in five tax treaties and 20 percent in one tax treaty. It appears that Canada has become increasingly likely to negotiate a rate of 10 percent with all countries (regardless of their income status), given that it has not granted a rate other than 10 percent since the Senegal treaty was signed in 2001 (Brooks, 2009:13). In the Canada/RSA tax treaty, a withholding tax of 6 percent is charged in Art 12(2) on royalties from copyright use and 10 percent on all other royalty income (see Table 2 ).

Table 2: Comparison of Withholding Tax Rates for Royalties

\begin{tabular}{|l|c|}
\hline Canada/RSA treaty & $6 \%$ for copyright and $10 \%$ for other income \\
\hline Canada's treaties with high and middle-income countries & $10 \%$ \\
\hline Canada's treaties with low-income countries & $10 \%, 12.5 \%, 15 \%$ or $20 \%$ \\
\hline OECD model & $0 \%$ \\
\hline UN model & None prescribed \\
\hline
\end{tabular}

\section{Dividends}

Both the OECD and UN models provide for split rates of withholding tax for dividend payments. If the taxpayer has a significant investment in the corporation paying the dividend, the withholding rate is typically lower than if the taxpayer is only holding a so-called portfolio investment. It is therefore necessary to distinguish between a significant investment, to which the lower rate will apply, and a portfolio investment.

In making this distinction, the OECD model has a much higher ownership threshold (25 percent) than the UN model (10 percent). The UN model commentary to Art 10(1) indicates that the 10 percent threshold is merely illustrative (UN, 2012:177). The former Group of Experts lowered the 25 percent to 10 percent because nonresidents in certain developing countries are limited to a 50 percent share ownership and 10 percent is a significant portion of such permitted ownership.

Canada's tax treaties set the ownership threshold for portfolio dividend treatment at different levels, but usually the rate is set at either 10 percent or 25 percent. According to Brooks (2009:13), the ownership rate is set at 10 percent in ten tax treaties with high-income countries, ten with middle-income countries, and ten with lowincome countries or 25 percent in three tax treaties with high-income countries, eight with middle-income countries, and four with low-income countries. In three cases of all low-income countries, there is no differential rate (i.e. the withholding tax rate is the same regardless of the share ownership). In one case, there are three possible rates, ranging from 5 to 15 percent.

The Canada/RSA tax treaty prescribes an ownership threshold of 10 percent in Art 10(2), thereby adhering to the UN model (see Table 3).

Table 3: Comparison of the Dividend Ownership Threshold

\begin{tabular}{|l|c|}
\hline Canada/RSA treaty & $10 \%$ \\
\hline Canada's treaties with high and middle-income countries & $10 \%$ or $25 \%$ \\
\hline Canada's treaties with low-income countries & $10 \%, 25 \%$ or no differential rate \\
\hline OECD model & $25 \%$ \\
\hline UN model & $10 \%$ \\
\hline
\end{tabular}


In terms of the withholding tax rates for significant investments, the OECD model prescribes a withholding tax of 5 percent. For portfolio investments, the maximum withholding tax is set at 15 percent. Paragraph 2 of the model reserves the right to tax to the state of source of the dividends; i.e., to the state of which the company paying the dividends is a resident. This right to tax, however, is limited considerably. ${ }^{11}$

The UN model does not prescribe any withholding tax rates. Per the UN model commentary to Art 10(1), the former Group of Experts was unable to reach a consensus on the maximum tax rates to be permitted in the source country (UN, 2012:178). It was noted that members from the developing countries, who basically preferred the principle of the taxation of dividends exclusively in the source country, considered that the rates prescribed by the OECD model would entail too large a loss of revenue for the source country. The UN model therefore leaves these percentages to be established through bilateral negotiations.

Canada is more likely to negotiate higher withholding tax rates with low-income countries. According to Brooks (2009:14), Canada has negotiated withholding tax rates for significant investments ranging from 5 percent to 20 percent. Treaties at 5 percent were negotiated with fifteen high-income countries, ten middle-income countries and eight low-income countries; 10 percent with one high-income country, eight middle-income countries and six low-income countries; 12.5 percent with one low-income country; 15 percent with one middle-income country and four low-income countries and 20 percent with one low-income country.

Article 10(2) of the Canada/RSA tax treaty sets the withholding tax rate at 5 percent for significant investments, thus echoing the proposed 5 percent of the OECD model (see Table 4).

Table 4: Comparison of the Dividends Withholding Tax Rate for Significant Investments

\begin{tabular}{|l|c|}
\hline Canada/RSA treaty & $5 \%$ \\
\hline Canada's treaties with high-income countries & $5 \%$ or $10 \%$ \\
\hline Canada's treaties with middle-income countries & $5 \%, 10 \%$ or $15 \%$ \\
\hline Canada's treaties with low-income countries & $5 \%, 10 \%, 12.5 \%$ or $20 \%$ \\
\hline OECD model & $5 \%$ \\
\hline UN model & None prescribed \\
\hline
\end{tabular}

In terms of the withholding tax rates for portfolio investments, Canada traditionally negotiated a withholding tax rate of 15 percent. This is the case, with the exception of one middle-income country and four lowincome country cases, where the portfolio withholding rates were set at 16 percent, 20 percent and 25 percent respectively (Brooks, 2009:14). In a few instances, Canada has agreed to non-reciprocal withholding tax rates. This is also the case with Art 10(2) of the Canada/RSA tax treaty (see Table 5). Generally, no exemptions are provided from dividend withholding tax, although Canada has negotiated four tax treaties that contain an exemption (Brooks, 2009:14). ${ }^{12}$

Table 5: Comparison of the Dividends Withholding Tax Rate for Portfolio Investments

\begin{tabular}{|l|c|}
\hline Canada/RSA treaty & Non-reciprocal \\
\hline Canada's treaties with high-income countries & $15 \%$ \\
\hline Canada's treaties with middle-income countries & $15 \%, 16 \%, 20 \%$ or $25 \%$ \\
\hline Canada's treaties with low-income countries & $15 \%, 16 \%, 20 \%$ or $25 \%$ \\
\hline OECD model & $15 \%$ \\
\hline UN model & None prescribed \\
\hline
\end{tabular}

\section{General Remarks}

Concerns were previously raised that the 'beneficial ownership' provision in South Africa's treaties did not contribute toward the curbing of treaty shopping. These concerns were based on the fact that South Africa did not impose withholding tax on dividends and interest earned by non-residents from a South African source (Oguttu, 2007:254).

\footnotetext{
${ }^{11}$ The OECD model commentary to Art 10 notes that the 15 percent appears to be a reasonable maximum figure. A higher rate could hardly be justified since the state of source can already tax the company's profits (OECD, 2010:187).

${ }^{12}$ South Africa is not one of the four countries to qualify for a dividend exemption.
} 
Section 35 of the Act provides for a withholding tax on royalties, which is levied on non-residents for the right of use in South Africa of any patent, design, trademark or copyright. The lack of withholding taxes on dividends and interest earned by non-residents from a South African source could plausibly have been viewed as a loophole in our law. Oguttu (2007:255) argues that this apparent loophole was covered by the (then) secondary tax on companies (STC) regime of the (former) section 64 of the Act, as well as the thin capitalisation rules of section 31(3) of the Act.

The perceived dividends loophole could be offset by the new dividends tax provisions introduced with effect 1 April, 2012, which replace the previous secondary tax on companies' regime. The new dividends tax provisions are contained in sections 64D to $64 \mathrm{~N}$ of the Act and are levied at 15 percent on dividends paid by companies. The revised dividend definition in section 1 of the Act now makes it clear that from 1 April, 2012, the dividend does not have to be paid to a shareholder; it merely has to be paid 'in respect of' a share in the company. Therefore, the beneficial owner need not be the registered owner of the share, but could be an agent or nominee holding the share on behalf of the beneficial owner (Haupt, 2012:404).

The aforementioned interest loophole appears to be covered by the thin capitalisation rules of section 31(3) of the Act. Basically, thin capitalisation refers to loans made by investors to companies, which are considered disproportionately large in relation to the equity of the company. The South African Revenue Service ('SARS') is then empowered to disallow the interest expense on the portion of the loan which is considered to be excessive. For years of assessment commencing on or after 1 April, 2012, section 31 is substantially revised and shortened. The general arm's length provisions will be used to determine whether a company is thinly capitalised.

Moreover, the latest legislative amendments seemingly plug any existing loopholes relating to interest, by subjecting international investors to a final 15\% withholding tax on interest income as from 1 July, 2013 (subject to tax treaty exemptions). The Taxation Laws Amendment Bill 2012 introduced sections 37I to 370 which apply to interest that accrues or interest that is paid or becomes due and payable on or after 1 July, 2013.

It could also be proposed that the articles in South Africa's treaties should not refer specifically to withholding taxes, but that a state of source may be entitled to tax up to a limited extent (Oguttu, 2007:258). It could arguably be more effective to incorporate objective rules in the form of limitation on benefits provisions in conjunction with current or enhanced beneficial ownership requirements (Loomer, 2009:39). Although Canada has shown some willingness to move in this direction in recent years, more is required to ensure a coherent and consistent approach to treaty shopping (Duff, 2010:24).

\section{CONCLUSION}

This paper has reviewed the concept of beneficial ownership in the context of double tax agreements between developed and developing countries. 'Beneficial ownership' is a unique treaty concept in the sense that it is used almost exclusively in treaties based on the OECD Model, and has no clear meaning under the domestic tax law of most countries ( $\mathrm{Li}, 2012: 189)$.

The extent to which a country's tax treaty policy favours developing countries or not depends upon the extent to which the country is prepared to adopt provisions from the UN model as opposed to the OECD model. When negotiating with developing countries, many developed countries are prepared to adopt some provisions from the UN model; this provides some indication of their concern that developing countries be able to retain their tax base in cross-border transactions (Brooks, 2009:2). The Canada/RSA treaty is largely based on the OECD model, with only the ownership threshold for the withholding of tax on dividends (viz. ten percent) incorporating the wording contained in the UN model. This could ostensibly be an indicator of Canada's relative lack of concern with the protection of South Africa's tax base.

It is submitted that the scope for the source taxation of passive investment income in the developing country could be magnified through treaty negotiations. This could be done by removing limitations on the withholding tax rates on passive investment income earned in the source country, including the withholding tax rates on payments of interest, dividends, and royalties. It was furthermore contended that the insertion into the Act of a 
general definition of 'beneficial ownership' would assist in the interpretation of the term for the purposes of South Africa's tax treaties.

Developing countries, in particular, should carefully consider the design of their tax treaty policy so as to effectively combat tax avoidance without sacrificing foreign direct investment. Striking the appropriate balance in tax treaty negotiations between developed and developing countries is indeed a challenging objective.

\section{AUTHOR INFORMATION}

Lee-Ann Steenkamp's Professional qualifications are Master Tax Practitioner (SA), Professional Accountant (SA) Academic qualifications: MComm (Tax) (Cape Town). She is a Senior Lecturer in the Department of Accounting at the University of the Western Cape, lecturing on undergraduate and postgraduate tax for students in the Chartered Accountant (SA) stream. E-mail: lee-ann@outlook.com

\section{REFERENCES}

1. Avi-Yonah, R. and HJI Panayi, C. (2010). Rethinking Treaty-Shopping Lessons for the European Union. University of Michigan Public Law Working Paper No. 182. Retrieved from: http://papers.ssrn.com/sol3/papers.cfm?abstract id=1531192 [11 January 2013].

2. Baistrocchi, E. (2008). The Use And Interpretation Of Tax Treaties In The Emerging World: Theory And Implications. British Tax Review 4 355-391.

3. Baker, P. (2008). The United Nations Model Double Taxation Convention Between Developed and Developing Countries: Possible Extension of the Beneficial Ownership Concept" - Annex to "Progress Report of Subcommittee on Improper Use of Tax Treaties: Beneficial Ownership". Retrieved from: http://www.un.org/esa/ffd/tax/fourthsession/EC18_2008_CRP2_Add1.pdf [20 February 2013].

4. Bakhru, P. and Gupta, N. (2012). Navigating Permanent Establishment In India. Retrieved from: http://www.internationaltaxreview.com/Article/3001108/Navigating-permanent-establishment-inIndia.html [13 April 2012].

5. Brooks, K. (2009). Canada's Evolving Tax Treaty Policy Toward Low-Income Countries. Retrieved from: http://papers.ssrn.com/sol3/papers.cfm?abstract id=1352647 [14 March 2012].

6. Christians, A. (2010). Taxation In A Time Of Crisis: Policy Leadership From The OECD To The G20. Northwestern Journal of Law and Social Policy 5(1) 18-40.

7. De Broe, L., Goyette, N., Martin, P., Rohatgi, R. Van Weeghel, S and West, P. (2011). Tax Treaties and Tax Avoidance: Application of Anti-Avoidance Provisions. Bulletin for International Taxation. IBFD: Netherlands.

8. De Koker, A.P. (2011). Silke on South African Income Tax. LexisNexis Butterworths Intranet Resources.

9. Duff, D.G. (2011). Tax Avoidance in the $21^{\text {st }}$ Century. Retrieved from: http://ssrn.com/abstract=1457453 [29 November 2011].

10. Duff, D.G. (2010). Responses To Tax Treaty Shopping: A Comparative Evaluation. Retrieved from: http://papers.ssrn.com/sol3/papers.cfm?abstract_id=1688689 [3 April 2012].

11. Du Plessis, I. (2012). Some Thoughts On The Interpretation Of Tax Treaties In South Africa. SA Merc LJ 24 31-52.

12. Elliffe, C. (2009). The Interpretation and meaning of 'beneficial owner' in New Zealand. British Tax Review, 3 1-31.

13. Haupt, P. (2012). Notes on South African Income Tax. Roggebaai: H\&H Publications.

14. Li, J. (2012). Beneficial Ownership in Tax Treaties: Judicial Interpretation and the Case for Clarity. Osgoode Hall Law School: Comparative Research in Law and Political Economy, 4 187-209.

15. Loomer, G.T. (2009). Tax Treaty Abuse: Is Canada Responding Effectively? Oxford University Centre for Business Taxation: Working Paper 09/05. Oxford University.

16. McIntyre, M.J. (2005). Developing Countries And International Cooperation On Income Tax Matters: An Historical Review, adapted and updated from Appendix B of Richard M Bird et al Tax Policy for Developing and Transitional Countries in the Global Economy (unpublished manuscript).

17. Meyer, S.P. (2010). The Meaning Of 'Beneficial Ownership' And The Use Thereof For Tax Treaty Shopping And And Tax Avoidance. Mini-dissertation: MComm. University of Pretoria: Pretoria. 
18. Oguttu, A.W. (2007). Curbing "Treaty Shopping": The "Beneficial Ownership" Provisions Analysed From A South African Perspective. Comparative and International Law Journal of Southern Africa, 40 237-258.

19. Organisation for Economic Cooperation and Development (OECD). (2010). Model Tax Convention on Income and on Capital. Retrieved from: http://www.oecd-ilibrary.org/taxation/model-tax-convention-onincome-and-on-capital-2010_9789264175181-en [8 October 2012].

20. Organisation for Economic Cooperation and Development (OECD). (2011). Global Forum on Transparency and Exchange of Information for Tax Purposes Peer Reviews: Canada 2011: Conbined: Phase $1+$ Phase 2. Retrieved from: http://dx.doi.org/10.1787/9789264110458-en [8 December 2012].

21. Organisation for Economic Cooperation and Development (OECD). (2013). Treaty Relief and Compliance Enhancement (TRACE) - Implementation Package Approved By CFA. Retrieved from: http://www.oecd.org/document/9/0,3746,en_2649 $33747 \quad 45700745$ 1_1_ 1 1_ 1,00.html [14 June 2013].

22. Reinhold, R.L. (1999-2000). What Is Tax Treaty Abuse? Is Treaty Shopping An Outdated Concept? Tax Lawyer, 53 663-670.

23. South Africa. (1997). Convention Between The Republic Of South Africa And Canada For The Avoidance Of Double Taxation And The Prevention Of Fiscal Evasion With Respect To Taxes On Income. Pretoria: Government Printer.

24. South Africa. (2009). The Constitution of the Republic of South Africa, Act 108 of 1996. Pretoria: Government Printer.

25. South Africa. (2012). The Taxation Laws Amendment Bill, B34-2012. Pretoria: Government Printer.

26. South Africa. (2013). The Income Tax Act, Act 58 of 1962. Pretoria: Government Printer.

27. South African Revenue Service (SARS). (2005). Discussion Paper On Tax Avoidance And Section 103 Of The Income Tax Act, 1962 (Act No. 58 of 1962). Pretoria: Government Printer.

28. The World Bank. (2013). Countries and Economics. Retrieved from: http://data.worldbank.org/country [14 June 2013].

29. United Nations (UN) Department of Economic and Social Affairs (DESA). 2012. United Nations Model Double Taxaction Convention Between Developed And Developing Countries. Retrieved from: http://www.un.org/en/development/desa/publications/double-taxation-convention.html [26 October 2012].

30. United Nations (UN) Statistics Division. (2013). Composition Of Macro Geographical (Continental) Regions, Geographical Sub-Regions, And Selected Economic And Other Groupings. Retrieved from: http://unstats.un.org/unsd/methods/m49/m49regin.htm\#developed [14 June 2013].

31. Van Weeghel, S. (1998). The Improper Use of Tax Treaties. The Hague: Kluwer Law International.

32. Vogel, K. (1977). Klaus Vogel on Double Taxation Conventions ( $3^{\text {rd }}$ ed). The Hague: Kluwer Law International. 
NOTES 